\title{
Ovulation Time Calculation Software Based on Pascal Language
}

\author{
Wisnu Kartika*1, Fariskha Novi Fauziah², Ahmad Syaifudin ${ }^{3}$ \\ ${ }^{1,2,3}$ Department of Medical Electronics, Faculty of Vocational and Universitas Muhammadiyah Yogyakarta \\ Jl. Brawijaya, Tamantirto, Kasihan, Bantul, +62 274387656 ext 455. \\ *Corresponding author, e-mail: wisnu2007@umy.ac.id
}

\begin{abstract}
On this time, it is many used devices for all of activity. On the daily life like watching $t v$, listening a radio, cooking with a stove and heating the water. All of that now use an embedded system, a small computing devices. In this era, many marriage couple who marry on the young age but they don't have much knowledge about marriage and ovulation. Ovulation is important for young marriage couple. Ovulation time is used for determine the time to us when we plan a time to have a baby. To determine the time for ovulation time using a method called ovulation method. Using this method we make a software. By using Delphi we can make a software which can calculate the time. It is very interesting. Copyright (C) 2017 Universitas Muhammadiyah Yogyakarta- All rights reserved.
\end{abstract}

Keywords: Ovulation Time, Delphi, Pascal Programming

\section{Introduction}

On this time, PC is changed by microcontroller for the embedded system. Embedded system is a system computer which has a special function which consist electric system, mechanical and software with limited computation with real time [1]. Ovulation time is also become a calculating for the young marriage couple [2]. There are young marriage couple who has not understand how it is important to know the fertile time and ovulation peak. If the the young marriage couple know this knowledge, it will easy to determine when ovarium is ovulated [3]. The background of this research is the knowledge of ovulation calculation and ovulation time is seldom to be talked [4]. So this knowledge is only known by medical people like midwifery and woman. This problem can be solved with making a simple software which can determine when the ovulation time occur. In this research, we propose a scheme by making a ovulation calculation software. This paper consists several parts. The explanation of literature review and research method will be explained on this paper. The conclusion will be shown in the last section.

\section{System Design}

The Haid time is started on the first day when the uterus has disintegrated and go out with blood from vagina. On the haid time, ovum will develop in ovarium. When the ovum has mature, the ovarium will free that ovum, that phenomenon is called ovulation [5].Generally, the ovulation happens 12 to 14 days before the next first haid day [6]. Actually, the day when ovulation is happened are depend on haid cycle on a woman [7]. If she has short cycle, for instance only 22 days, so the ovulation only can happen after the haid time is ended [8]. Fertil time a woman is 12 to 16 [9].

Borland Delphi 7 is a software Integrated Development Environment (IDE) which use a Pascal Language as basic language. Borland Delphi 7 has visualization which enough easy for user to make a software which is used Graphic User Interface (GUI). GUI is a kind of interface which is used user to interact with electronic devices (like a computer, handphone, etc.) which not a text.

Integrated Development Environment (IDE) is a part which display the interface and tools. There are several part of this IDE that is

1. Welcome Page

2. Forms 
3. Designer Surface

4. Tool Palette

5. Object Inspector

6. Object Repository

7. Project Manager

8. Data Explorer

9. Code Editor

10. To-Do Lists

TABLE I

A Simple OF OBJeCt INSPECTOR [10]

\begin{tabular}{|c|c|c|}
\hline Komponen & Properti & Nilai \\
\hline Label1 & $\begin{array}{l}\text { Caption } \\
\text { Font }\end{array}$ & $\begin{array}{l}\text { Make A Software } \\
\text { Times New } \\
\text { Roman/Bold/20pt }\end{array}$ \\
\hline Label2 & $\begin{array}{l}\text { Caption } \\
\text { Font }\end{array}$ & $\begin{array}{l}\text { Wisnu } \\
\text { Times New } \\
\text { Roman/Bold/14pt }\end{array}$ \\
\hline $\begin{array}{l}\text { Button1 } \\
\text { Button2 } \\
\text { Button3 } \\
\text { Label1 }\end{array}$ & $\begin{array}{l}\text { Caption } \\
\text { Caption } \\
\text { Caption } \\
\text { Caption } \\
\text { Font }\end{array}$ & $\begin{array}{l}\text { Tampil } \\
\text { Sembunyi } \\
\text { Tutup } \\
\text { Make A Software } \\
\text { Times New } \\
\text { Roman/Bold/20pt }\end{array}$ \\
\hline
\end{tabular}

TABLE II

ARITHMATIC OPERATOR [10]

\begin{tabular}{llll}
\hline \hline Operator & Operation & Data Type & Result Type \\
& & & \\
\hline+ & Add & $\begin{array}{l}\text { Integer } \\
\text { Real }\end{array}$ & $\begin{array}{l}\text { Integer } \\
\text { Real }\end{array}$ \\
- & Substract & & \\
$*$ & Multiply & & \\
$/$ & Division & & \\
Div & Pembagian & & \\
Mod & Bulat & Integer & Integer \\
\hline \hline
\end{tabular}

\section{Borland}

Delphi

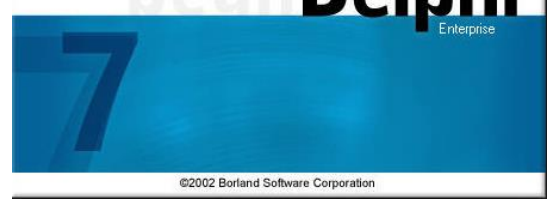

Fig. 1. Software Borland Delphi 7

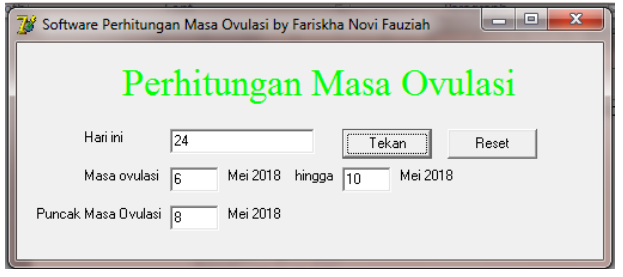

Fig. 2. Simulation Program Result

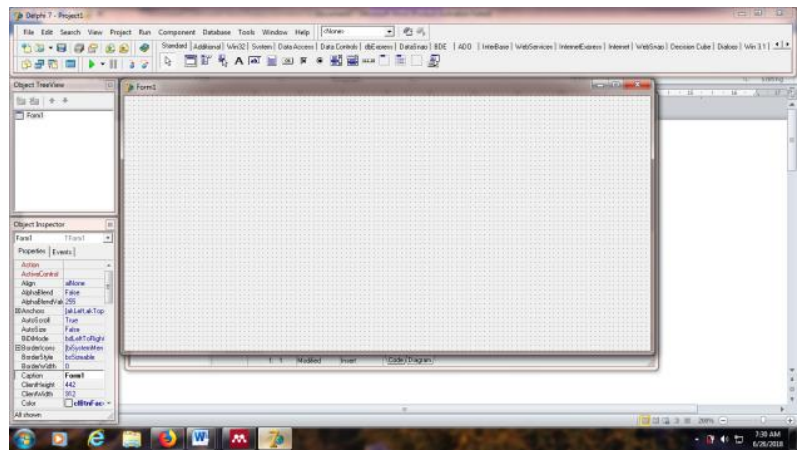

Fig. 3. Interface of Delphi Software

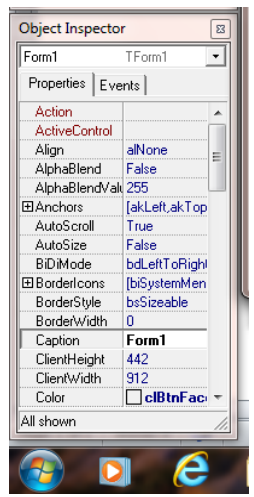

Fig. 4. Object Inspector

Standard |Additional | Win32 | Sustem | DataAccess | Data Controls | dbExoress | DataSnao | BDE | ADO | Interbase | WebServices | InternetExoress | Internet | W

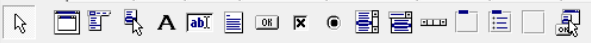

Fig. 5. Icon To Make A Component

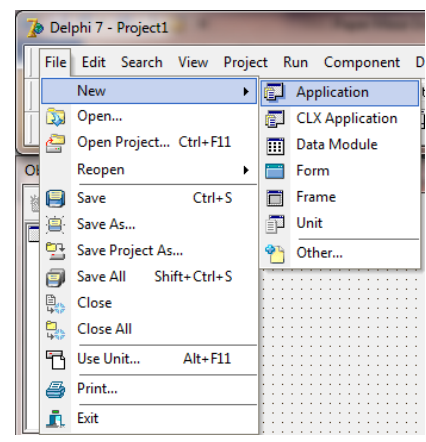

Fig. 6. A Step to Make A New Project

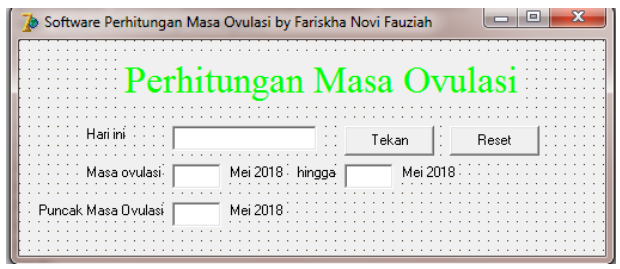

Fig. 7. Interface 
procedure TForm1.Button2Click (Sender: TObject);
begin

Fig. 8. Clear Function

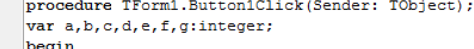

Fig. 9. Input The Data

$\bar{g}:=\bar{e}-30 ;$

Edit2. Text:=Inttostr(f)

Edit3.Text: $=$ Inttostr $(g)$

Edit4.Text:=Inttostr(c)

Fig. 10. Output and Display

\section{Experiment}

This software is made in a version. The version is on Borland Delphi. On the previous research who is done [5] using Android application. The application can show the date in real time and can calculate the time of fertile time and remark it on a calendar. This is very important to know the date in a calendar and to determine what day which they need to wait in to the proper date. Our research is simple and applicable. The advantage of our research is the software can be applied in the cross platform. The application can be run on Windows, Macintosh, and Linux (Ubuntu). Our research also include fertile time. This research using the open source software so it can be tried by much researcher or students.

\section{Methodology and Result}

The explanation using Borland Delphi 7 will be explained on this section.

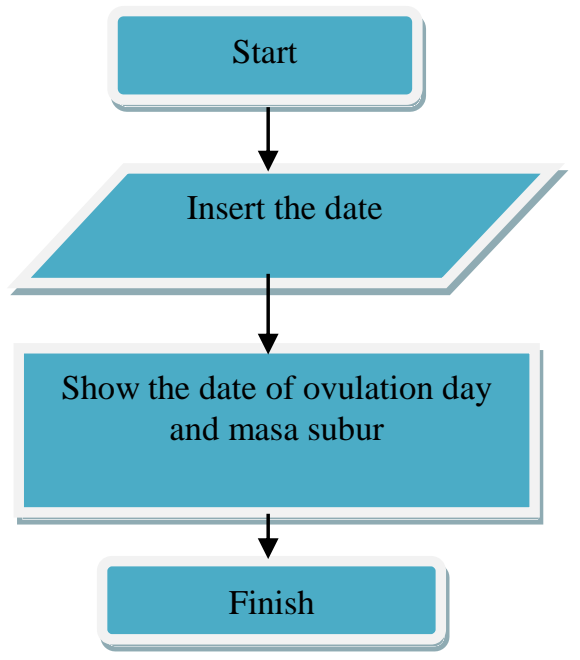

Figure 11 Flowchart of Process Program Running
This section we use several component like four Edit and eight Label and two Button. The command we use InttoStr and StrtoInt.

This is the explanation of the source code. We insert the date and then press the Tekan button so it will display ovulation peak and the range of masa subur.
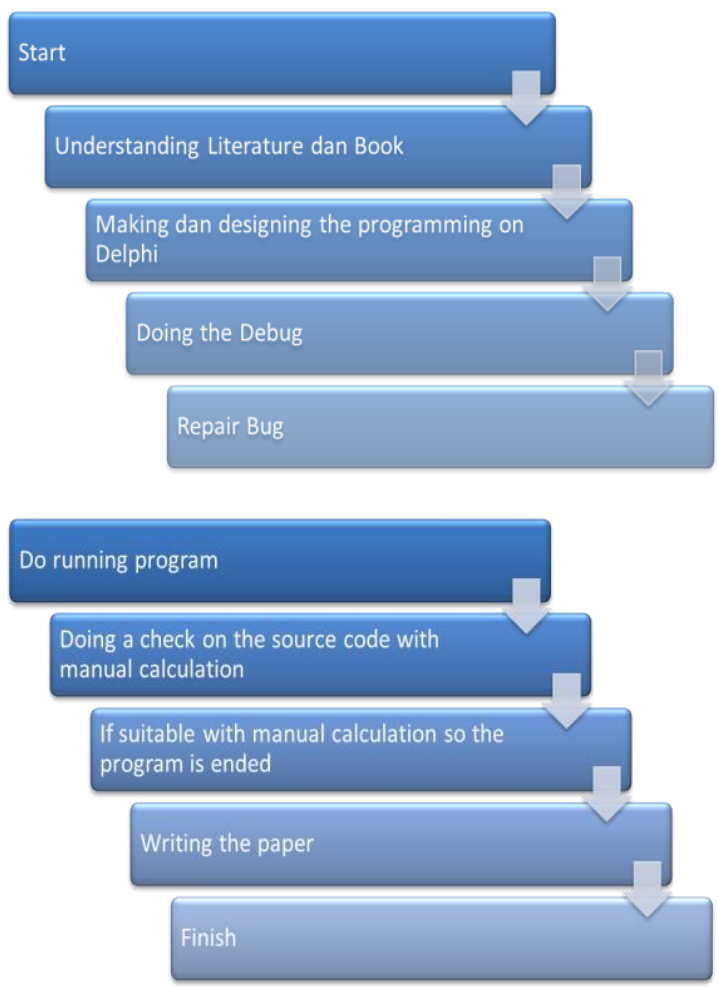

Figure 12 Flowchart of the Research Method

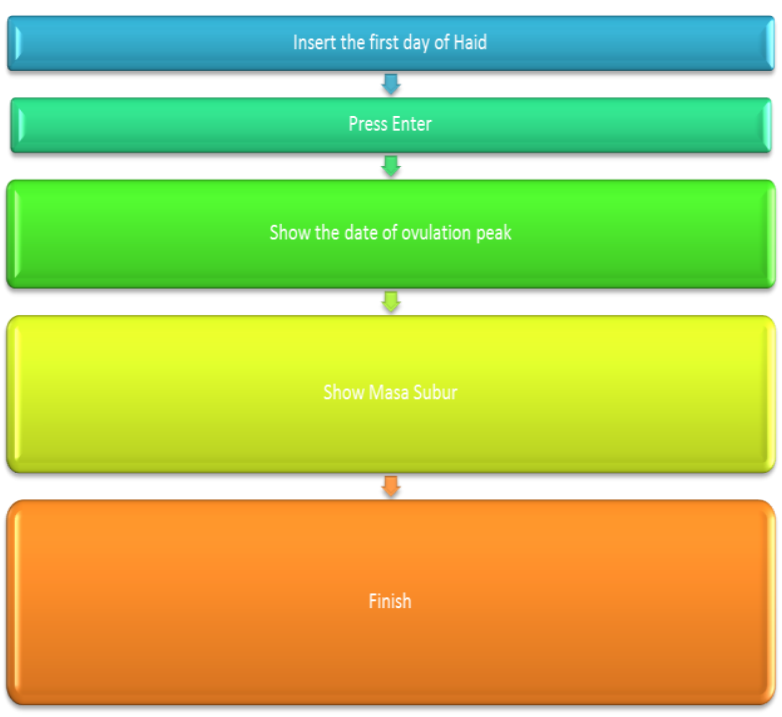

Figure 13 User Manual of Delphi 
TABLE III

DATA TYPE [11]

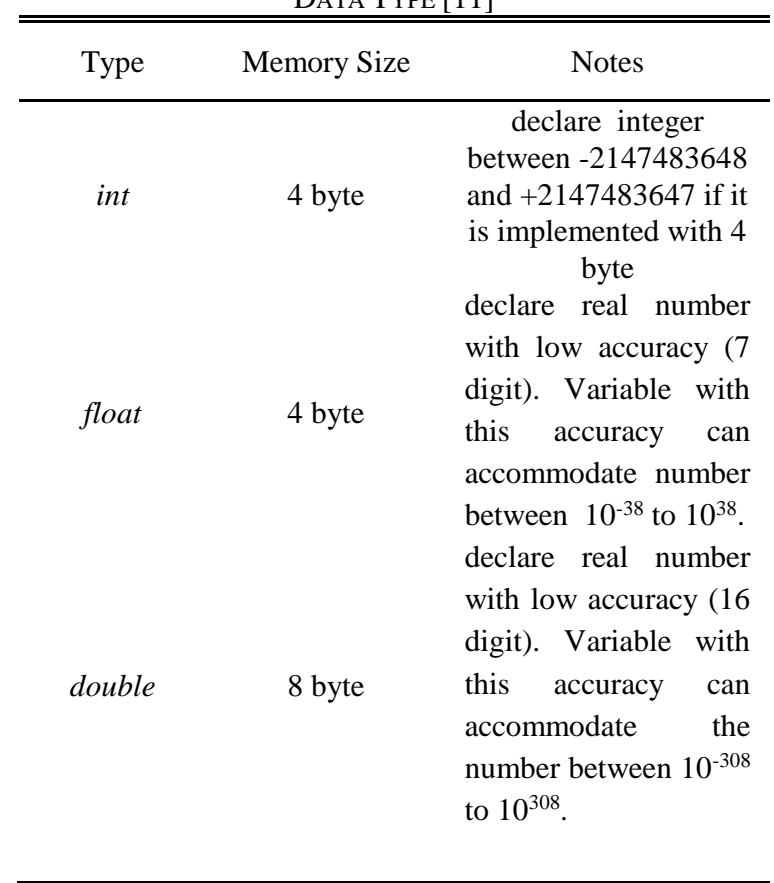

with 1 byte $=8$ bit.

\section{Conclusion}

Our conclusion is with this software we can determine a time of peak ovulation. This software can help usual people who has marriage.

\section{Appendix}

Appendixes, if needed, appear before the acknowledgment.

\section{Acknowledgements}

This work was supported by Universitas Muhammadiyah Yogyakarta. We say thankful to my mother and my wife and our friends who help me to make this paper.

\section{References}

[1] A. Bejo, Rahasia Kemudahan Bahasa C dan CVAVR. Graha Ilmu, 2008.

[2] M. Burkhart, S. S. M. L. De, and V. M. Lampreeht, "Effectiveness of a Standard-Rule Method of Calendar Rhythm Among Mayan Couples in Guatemala.pdf," International Family Planning Perspectives, vol. 26, pp. 131-136.
[3] M. Arevalo, I. Sinai, and V. Jennings, “A Fixed Formula to Define the Fertile Widow of the Menstrual Cycle as the Basis of a Simple Method of Natural Family Planning."

[4] D. Scutt and J. T. Manning, "Symmetry and ovulation in women," vol. 11, no. 11, pp. 24772480, 1996.

[5] S. F. Atika, M. Yunus, and L. A. Primandari, "Aplikasi Penghitung Masa Subur Wanita Berbasis Android," Seminar Nasional Sistem Informasi 2017 Fakultas Teknologi Informasi UNMER Malang, no. September, pp. 699-708, 2017.

[6] D. A. Lupinska and D. M. J, “A Comparison of Popular Fertility Awareness Methods to a DBN Model of the Woman's Monthly Cycle," Sixth European Workshop on Probabilistic Graphical Models, 2012.

[7] E. M. Sitompul, Panduan Pintar Menghitung Masa Subur. Jakarta: Kunci Aksara, 2015.

[8] R. J. Fehring, "New Low- and High-Tech Calender Methods of Family Planning," Journal of Midwifery \& Women's Health, 2005.

[9] Y. Puspita, Panduan Cepat Mendapatkan Buah Hati. Jogjakarta: Stiletto Book, 2016.

[10] Pujianto, Praktis Belajar Borland Delphi 8.0 Bagi Pemula. Graha Ilmu, 2007.

[11] A. Kadir, From Zero to A Pro Pemrograman $C$. Penerbit Andi, 2015.

\section{Authors' information}

The photographs, names, the vitae, the affiliation and the research interests of the authors should be given at the end of the paper.

The photo must be $2.45 \mathrm{~cm} \mathrm{x} 2.45 \mathrm{~cm}$. The text $(9 \mathrm{pt})$ wrapping style must be around the frame.

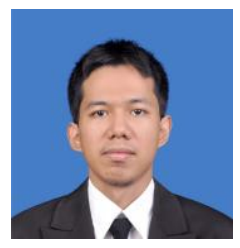

Wisnu Kartika was born on Yogyakarta May $12^{\text {th }} 1989$. He graduated from Electrical Engineering Universitas Gadjah Mada, Yogyakarta, Indonesia during eight years on Bachelor and Master Degree. He major on Data Communication Error Correction. Wisnu Kartika, S.T., M.Eng. 


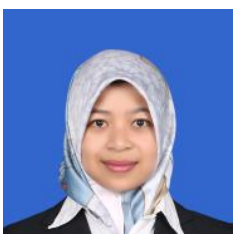

Fariskha Novi Fauziah was born on October $26^{\text {th }} 1994$ at Temanggung. She graduated S.ST on Midwifery, Universitas Respati Yogyakarta, Indonesia during four years.

Fariskha Novi Fauziah, S.ST.

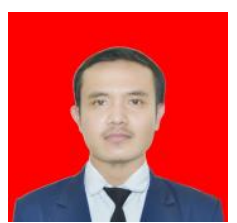

Ahmad Syaifudin was born on April $1^{\text {st }}$ 1992 at Ponorogo gradusted from Poltekkes Kemenkes Surabaya during three years.

Ahmad Syaifudin, A.Md. TEM. 